\title{
SPATIAL \& TEMPORAL WATER BALANCE ANALYSIS CONSIDERING STRUCTURAL \& NON-STRUCTURAL MEASURES IN THE CISANGKUY RIVER BASIN
}

\section{ANALISIS NERACA AIR RUANG DAN WAKTU, MEMPERTIMBANGKAN UPAYA STRUKTURAL DAN NON-STRUKTURAL STUDI KASUS DAS CISANGKUY}

\author{
IH Ko') W Putuhena') I. Sudono') YJ Kim³) TW Kim ${ }^{4)}$ \\ ${ }^{1)}$ Yooshin Engineering Corporation, Seoul, Korea \\ ${ }^{2)}$ PusAir, Ministry of Public Works and Public Housing, Indonesia \\ ${ }^{3)}$ RNAsolution, Seoul, Korea \\ ${ }^{4)} \mathrm{GTE}$, Seoul, Korea
}

\begin{abstract}
The Cisangkuy river basin located in the south of Bandung Metropolitan has been suffering from serious water scarcity, river pollution, and flood damage due to rapid increase in population and industrialization in the Bandung Metropolitan and surrounding upstream area. In order to solve these complicated water management issues, it needs to implement innovative measures for integrated basin water management. As part of these efforts, a cooperative research project between Indonesia and Korea has initiated to develop smart water management system in the Cisangkuy river basin. This paper deals with the spatial-temporal water balance analysis and shows the results of effect analysis with regard to structural measures and nonstructural measures. As the result of analysis, the power generation capacity and water supply safety are improved by 1.4 2.7\% and 0.8 1.2\%, and water shortage is decreased from 223 days to 190 days in case of the implementation of non-structural measures. It shows that new operation rule will contribute not only for securing additional water through the implementation of non-structural measures but also improvement of water facilities management efficiency. In case of applying the planned intake (3.3 $\mathrm{m} 3 / \mathrm{s})$ under current water supply system, water supply safety was decreased by $8.3 \%(92.3 \rightarrow 84.0)$ at the Cikalong Intake and decreased by $12.5 \%(75.3 \rightarrow 62.8)$ at the Pataruman gauge station in the Cisangkuy river (Q95\% condition) respectively in comparison with present intake condition. It indicates that additional water supply is necessary to meet the increased water demand. Alos according to the evaluation on the effect of new Cikalong dam, consistent water supply $\left(0.35 \mathrm{~m}^{3} / \mathrm{s}\right)$ is possible at Cikalong intake station. However, water supply safety at Pataruman for river maintenance flow and Ciherang irrigation water were decreased by $2.4 \sim 4 \%$.
\end{abstract}

Keyword: Water, smart water management, water balance analysis, coordinated operation, structural \& non-structural measures, integrated basin water management

\begin{abstract}
ABSTRAK
Daerah aliran Sungai (DAS) Cisangkuy terletak di selatan Bandung Metropolitan telah menderita kelangkaan air secara serius, pencemaran sungai, dan kerusakan akibat banjir dikarenakan peningkatan pesat jumlah penduduk dan industrialisasi di Metropolitan Bandung dan bagian hulu. Dalam rangka Mengatasi masalah pengelolaan air yang pelik ini, perlu menerapkan langkah-langkah inovatif dalam pengelolaan sumber daya air terpadu. Sebagai bagian dari upaya tersebut, proyek penelitian kerjasama antara Indonesia dan Korea telah menginisiasi untuk mengembangkan sistem pengelolaan air cerdas di DAS Cisangkuy. Tulisan ini terkait analisis neraca air spasial-temporal dan menunjukkan hasil analisis dampak dari tindakan-tindakan upayaperbaikan secara struktural dan non-struktural. dimana Hasil dari analisis menunjukan bahwa upaya non-struktural meliputi koordinasi dan optimalisasi operasi bangunan air dapat berkontribusi tidak hanya untuk menjamin penambahan air tetapi juga untuk mempromosikan kolaborasi pengelolaan sumber daya terpadu.
\end{abstract}

Kata Kunci: Air, Pengelolaan Sumber daya air cerdas, analisa neraca air, koordinasi pengoperasian, upayaupaya struktural \& non-structural, Pengelolaan Sumber daya air terpadu 


\section{INTRODUCTION}

One of the major challenges for sustainable development faced by both the developed and developing countries is to ensure that all people continue to have reliable access to water service. According to the UN World Water Development Report, by 2050, at least one in four people are likely to live in a country affected by chronic or recurring shortages of freshwater (ITU, 2010). Therefore, sustainable water resources management policies have been high priority on the agenda of many governments around the world. Furthermore, the impact of climate change in terms of sea level rise, longer drought periods and severe flooding is adding more serious pressure on the availability of water resources for global communities to sustain water welfare and economic growth (IBM, 2013).

The Cisangkuy river basin, located in the south of Bandung Metropolitan in West Java Province Indonesia, is under unfavourable circumstances in water management. In the basin, Bandung Metropolitan is one of the most socially and economically progressive area with heavy population density of $900 / \mathrm{km}^{2}$. While water resources of the basin are relatively abundant, competition for these resources has increased significantly over the past 20 years leading to a situation of acute water and environmental stress in the region (D. Subarna et.al, 2014). The increasing huge demand of water for the mega city and deforestation in the upstream area accelerated river pollution, and flood damage. Furthermore, poor water facilities operation capacity with fragmented water management governance is deteriorating conflict among stakeholders in water resources management.

In order to solve these complicated water management issues, it needs to implement innovative measures for integrated basin water management. As part of these efforts, a cooperative research project between Indonesia and Korea has recently initiated to develop smart water management system in the Cisangkuy river basin. This project titled 'Development of Smart Water Management System in Cisangkuy River Basin' is to provide decision support tool for the optimized water supply and maximized water use efficiency through coordinated multi-water facilities (dam, weir and power plant etc.) operation. The project is implemented by Korea Agency for Infrastructure Technology Advancement (KAIA). Under the support and supervision of KAIA, Korean study team is carrying out the research project in close collaboration with Indonesian counterpart agency, National Research Centre for Water Resources (PusAir).
This paper provides preliminary analysis results of initial phase study to examine potential effectiveness and feasibility of applying smart water management technologies. Also this paper deals with the spatial-temporal water balance analysis and shows the results of effect analysis with regard to implementation of structural measures and non-structural measures.

\section{THE CHARACTERISTICS OF STUDY AREA}

\section{Basin Characteristics}

As shown in the Figure 1, the Cisangkuy river is located in the upstream of the Citarum river. The catchment area of the river is $283.7 \mathrm{~km}^{2}$, The average watershed altitude is El. $1465.2 \mathrm{~m}$, and the average basin slope is $26.82 \%$. Water flows from south to north in the project area. Among the total cropping land with $154.3 \mathrm{~km}^{2}$ in the basin, 28 $\mathrm{km}^{2}$ is for dry field (18.1\%), $19.7 \mathrm{~km} 2$ is for rice paddy $(12.76 \%)$, and $70.4 \mathrm{~km}^{2}$ is for forests (45.61\%).

\section{Hydro-meteorological Characteristics}

According to the recorded meteorological data at Bandung station operated by the BMKG (Badan Meteorologi, Klimatologi Dan Geofisika), monthly average temperature is $23.27^{\circ} \mathrm{C}$, (maximum $32.3^{\circ} \mathrm{C}$ and minimum $16.7^{\circ} \mathrm{C}$ ), and the percentage of sunshine is $58.1 \%$ in the region. Two flow measurement stations (Pataruman and Kamazan) are operated by BBWSC in the Cisangkuy basin. Flow regime analysis was made at Pataruman gauge station with recent 10 years historic flow data (2003 2012). The average drought flow is $3.18 \mathrm{~m}^{3} / \mathrm{s}$, and $95 \%$ flow is 3.37 $\mathrm{m}^{3} / \mathrm{s}$.

\section{Status of Water Facilities}

Cisangkuy river, a tributary of the upper CRB, is one of the main water sources to Bandung. In this project area, two existing hydropower dams and reservoirs (Cipanunjang, Cileunca), three micro hydropower plants (Plengan, Lamajan, Cikalong), two tunnels and one water intake (Cikalong) are operated as shown in the Figure 2. In addition, a new dam (Santosa and Cikalong) construction is under planning as part of the project to increase water supply capacity to Bandung region (Yooshin, 2013).

\section{Dams and Reservoirs}

Cipanunjang and Cileunca dams and reservoirs managed by Indonesian Power were constructed for hydropower generation purpose. Natural overflow through Morning-glory type spillway is practiced during flood control operation. Maximum $5.5 \mathrm{~m}^{3} / \mathrm{s}$ of water is released from Cipanunjang to Cileunca reservoir through gate installed in the water intake. From Cileunca reservoir, maximum $6 \mathrm{~m}^{3} / \mathrm{s}$ is supplied to the 
Spatial and Temporal Water balance Analysis Considering Structural and ...(Ih Ko, etc)

three micro hydropower plants (Plengan, Lamajan, Cikalong) in downstream which are operated by PLTA. Table 1 summarizes main features of the two hydropower reservoirs.
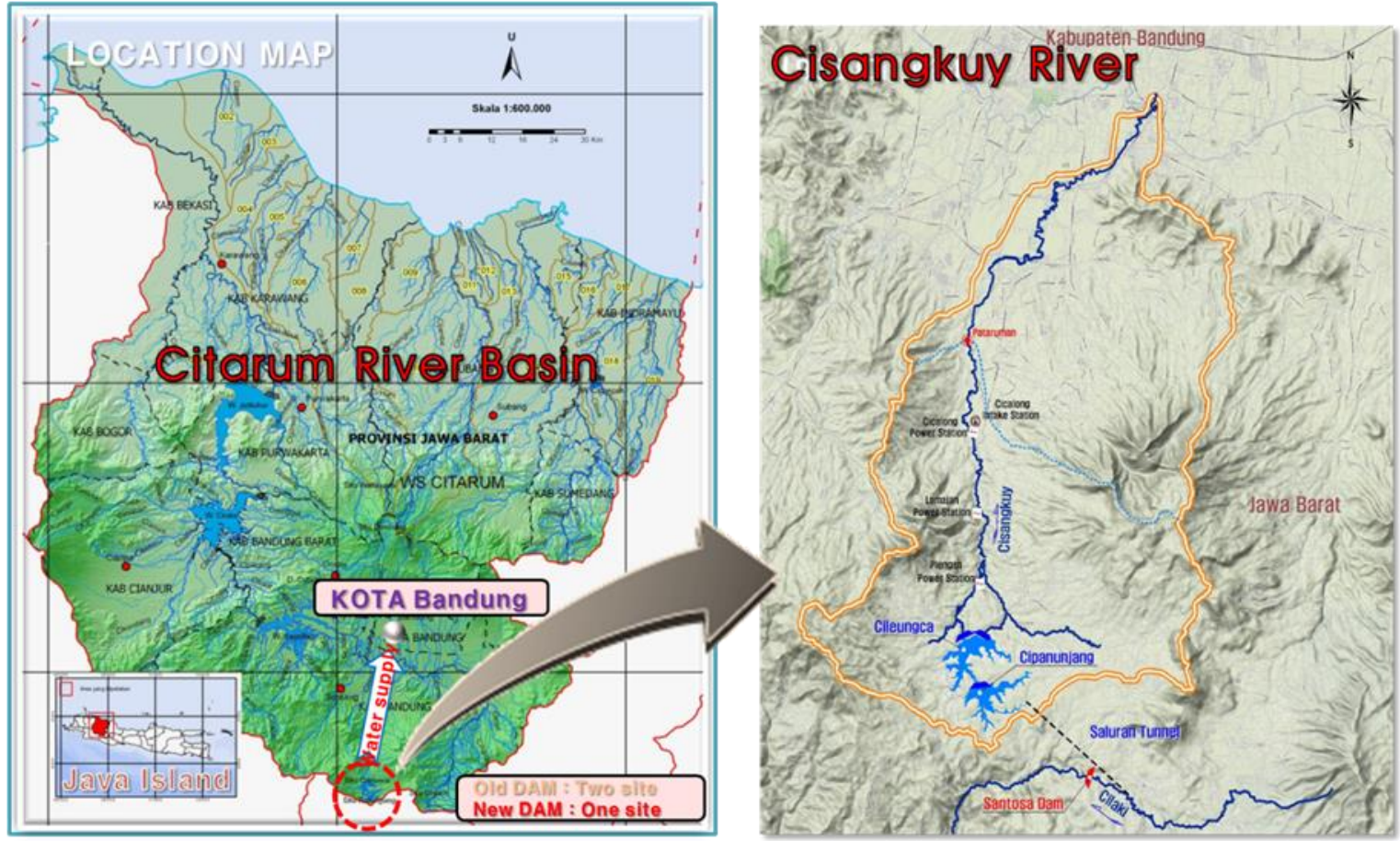

Figure 1 Map of CRB and Cisangkuy Project Area in the Upper CRB

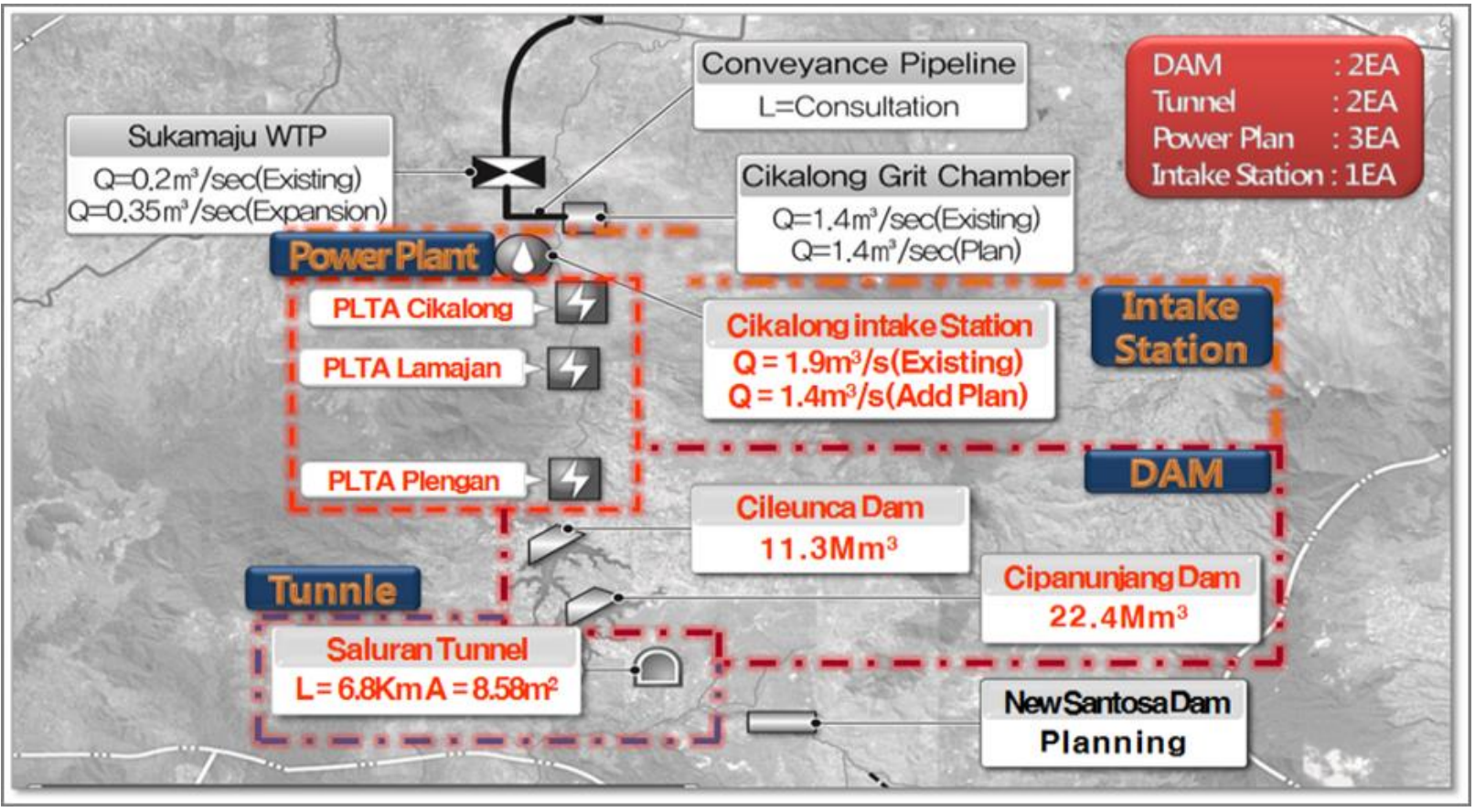

Figure 2 Water Facilities 
Jurnal Sumber Daya Air Vol. 14 No.2, Desember 2018: 87 - 96

Table 1 Main Features of Existing Hydropower Reservoirs

\begin{tabular}{c|c|c|c|c}
\hline Classification & $\begin{array}{c}\text { Year of } \\
\text { Completion }\end{array}$ & $\begin{array}{c}\text { NHWL } \\
\text { (EL. m) }\end{array}$ & $\begin{array}{c}\text { DWL } \\
\text { (EL. } \mathbf{m})\end{array}$ & $\begin{array}{c}\text { Effective Storage } \\
\text { ( }^{\mathbf{3}} \mathbf{)}\end{array}$ \\
\hline Cipanunjang & 1930 & $1,446.0$ & $1,432.6$ & $16,900,000$ \\
\hline Cileunca & 1924 & $1,418.5$ & $1,408.2$ & $11,230,000$ \\
\hline
\end{tabular}

Table 2 Main Features of the Three Micro Hydropower Plants

\begin{tabular}{c|c|c|c}
\hline Classification & Plengan & Lamajan & Cikalong \\
\hline Number of turbine & 5 & 3 & 3 \\
\hline Type & Francis Horizontal & Francis Vertical & Francis Horizontal \\
\hline Capacity & $3 \times 1500,1 \times 2900,1 \times 2280$ & $3 \times 9000$ & $3 \times 9000$ \\
\hline rpm & $750 \sim 600$ & 600 & 750 \\
\hline Qpower $\left(\mathrm{m}^{3} / \mathrm{s}\right)$ & $3 \times 1.6,1 \times 2.85,1 \times 2$ & 3.90 & 5.50 \\
\hline Head $(\mathrm{m})$ & 90 & 216 & 140 \\
\hline Year of Completion & $1922,1962,1996$ & 1925,1934 & 1961 \\
\hline
\end{tabular}

Table 3 Scenarios for Water Balance Analysis

\begin{tabular}{c|l|c}
\hline Scenario No. & \multicolumn{1}{|c}{ Description } & Type of Measure \\
\hline Case 1 & $\begin{array}{l}\text { Evaluation of improving the operational efficiency at } \\
\text { existing hydropower dams }\end{array}$ & Non-Structural \\
\hline Case 2 & $\begin{array}{l}\text { Review of water supply plan with new Santosa dam } \\
\text { construction }\end{array}$ & Structural \\
\hline Case 3 & $\begin{array}{l}\text { Evaluation on the effect of new Cikalong dam } \\
\text { construction }\end{array}$ & $\begin{array}{l}\text { Review of the changing reservoir volume with dredging } \\
\text { impact }\end{array}$ \\
\hline
\end{tabular}

\section{Micro Hydropower Plants}

Table 2 summarizes main features of the three micro hydropower plants in the project area.

\section{Water Intake}

Cikalong Water Intake is located at the downstream of the Cikalong Micro Hydropower Plant. The capacity of current water intake is 1.9 $\mathrm{m}^{3} / \mathrm{s}\left(1.4 \mathrm{~m}^{3} / \mathrm{s}\right.$ for raw water, $0.5 \mathrm{~m}^{3} / \mathrm{s}$ for treated water). It will be increased through a new dam construction by $1.4 \mathrm{~m}^{3} / \mathrm{s}$.

\section{METHODOLOGY}

For stable water supply planning, it is necessary to be confirmed through water balance analysis (WBA). Also, the basis of comprehensive WBA is essential for integrated and coordinated water infrastructures operation in the project area considering new dam (Cikalong), existing hydropower reservoirs (Cipanunjang, Cileunca), micro hydropower plants (Plengan, Lamajan, Cikalong), intake (Cikalong), irrigation water demand, and environmental flow for the downstream of the Cisangkuy river.

KModSim, a Generalized river basin network model jointly developed by K-water Institute and
Colorado State University, was applied for this WBA study (CSU, 2010). KModSim is designed as a computer-aided tool for developing improved basin wide and regional strategies for short-term water management, long-term operational planning, drought contingency planning, water rights analysis and resolving conflicts between urban, agricultural, and environmental concerns. Especially, this model includes scenario evaluation tools, probabilistic and flow duration curves for Monte Carlo analysis, and animated visualization of simulation results.

Simulation network was established by dividing the project basin into 30 sub-basins reflecting main water infrastructures, facilities, and tributary inflow with reference to the Pataruman gauge station as shown in Figure 3.

Based on the network, water supply safety for the main control points were analysed with current and improved operation conditions at the Cipanunjang and Cileunca reservoirs as nonstructural manners. In addition, the effect of new dam construction and reservoir dredging as structural measures was reviewed considering the increased inflow scenario as shown in Table 3. 


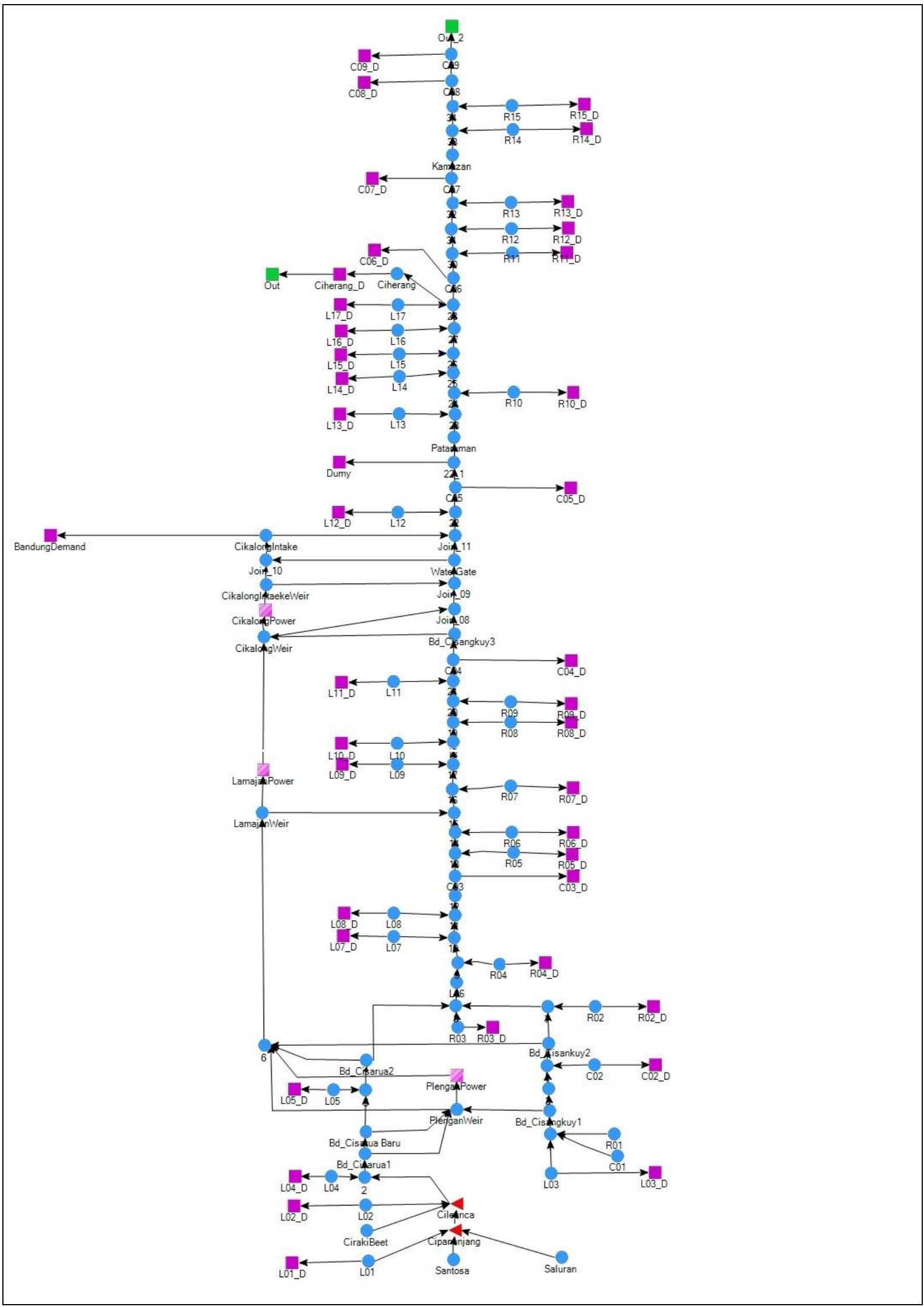

Figure 3 Schematic Diagram of the KModSim Network Simulation Model 


\section{WATER BALANCE ANALYSIS CONSIDERING IMPLEMENTATION OF NON-STRUCTURAL MEASURES}

For water balance analysis regarding nonstructural measures, optimal and coordinated reservoir operation rule was derived. And then this new reservoir operation rule curve is compared to current operation condition to find out the possibility of improving its operational efficiency for water supply. In order to set up optimal operating curve, historic reservoir pattern and downstream demand condition were to be identified. New reservoir operation curve of Cipanunjang and Cileunca were derived to satisfy downstream water demand considering current operation pattern as shown in the Figure 4. It shows consistent pattern by dry and wet season of the years. From December to February in the following year, the reservoirs store water to supplement the released water during dry season. It continues until May. Then the reservoirs release water from June to November for irrigation.

Analysis was conducted by applying current operating pattern curve and modified new operating curve derived from water balance analysis. Analysis condition and result are described in the following.

\section{Analysis Condition}

It was applied modified reservoir operating curve that keeps more storage to increase electric power generation and meets water supply safety regarding water shortage in dry season. Analysis condition in this case is shown as below;

Period: 2002 2012 (11 years, Daily)

1. Intake $1.9 \mathrm{~m}^{3} / \mathrm{s}$ water from Cikalong intake station

2. Hydropower plants: Monthly average generation capacity, 9 years (2004 2012)

3. Reservoir operation curve that keeps more storage to increase electric power generation and meets safety degree of water shortage in dry season through trial and error method. Applied operating curves are as shown in Figure 5.

\section{Result}

The results are comparing the performance at existing and modified operation is summarized in the Table 4 and 5 . As shown in the Table 4 and 5, the power generation capacity and water supply safety are improved and water shortage is decreased. It shows that new operation rule will contribute not only for securing additional water through the implementation of non-structural measures but also improvement of water facilities management efficiency.

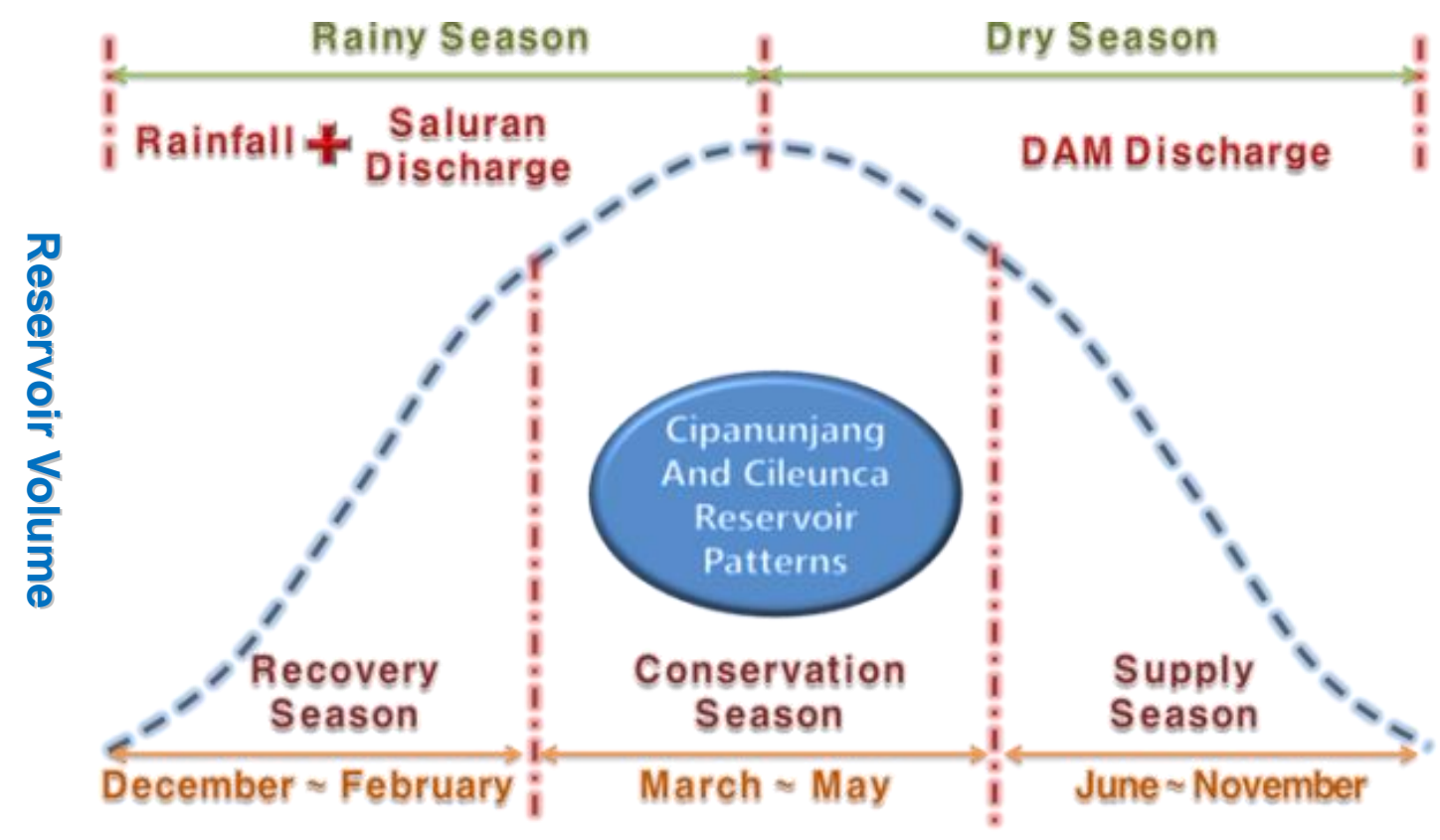

Figure 4 The optimal operation curve 
Spatial and Temporal Water balance Analysis Considering Structural and ...(Ih Ko, etc)
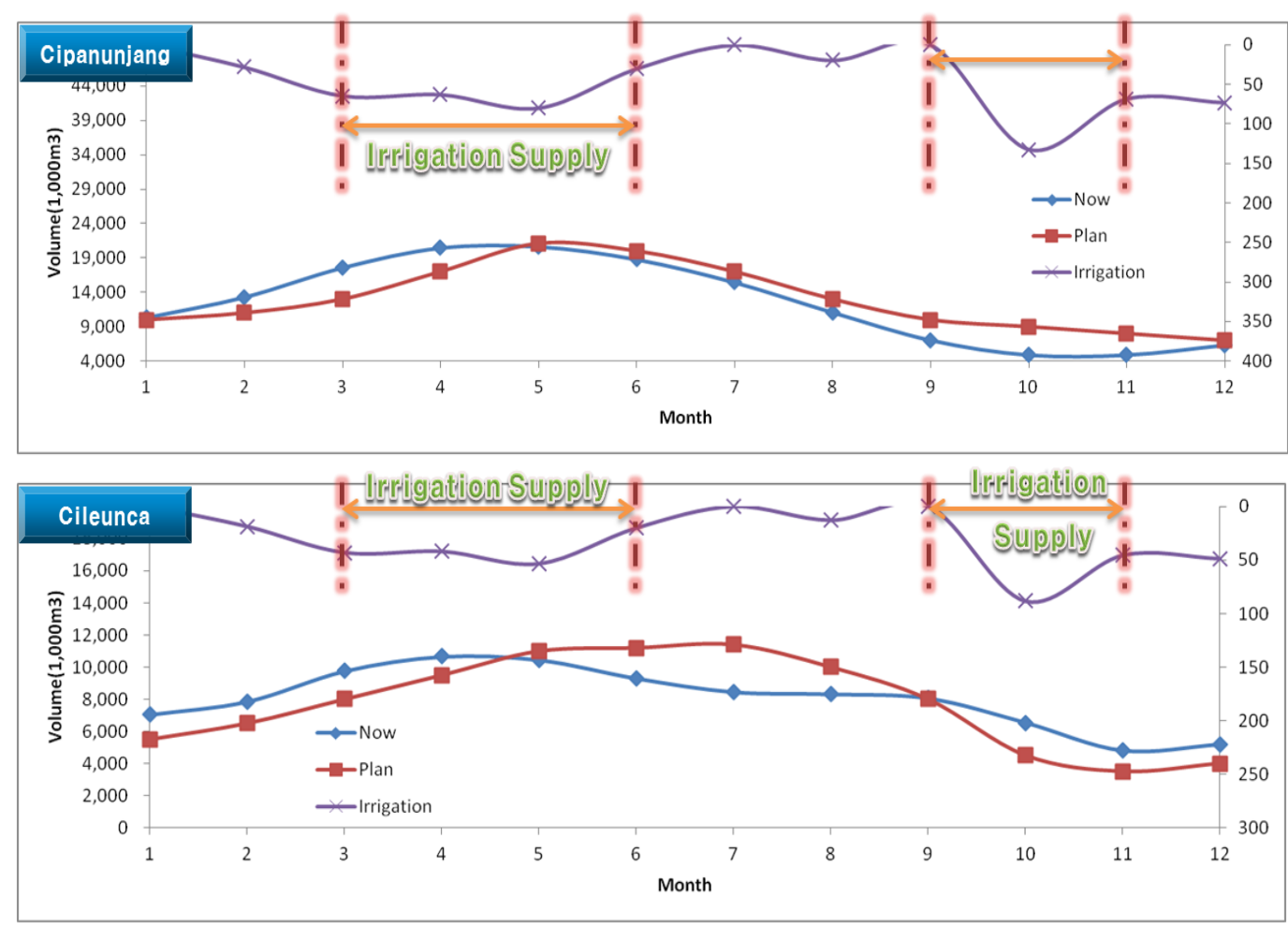

Figure 5 Current and Modified Operation Curves of Reservoirs

Table 4 Comparison of power generation capacity

\begin{tabular}{|c|c|c|c|c}
\hline \multicolumn{2}{|c|}{ Item } & \multicolumn{3}{c}{ Annual Average Capacity $\left(1,000 \mathrm{~m}^{3}\right) \rightarrow$ Supply at Dry Season } \\
\cline { 3 - 5 } & Current Operation & Modified Operation & Result \\
\hline \multirow{2}{*}{ Power Plant } & Plengan & 534,255 & 548,366 & $\mathbf{\Delta} 14,111(2.64 \%)$ \\
\cline { 2 - 5 } & Lamajan & 572,477 & 587,981 & $\mathbf{\Delta} 15,504(2.71 \%)$ \\
\cline { 2 - 5 } & Cikalong & 618,352 & 639,375 & $\mathbf{\Delta} 8,717(1.41 \%)$ \\
\hline
\end{tabular}

Table 5 Comparison of water supply safety

\begin{tabular}{|c|c|c|c|c|c|c|c|}
\hline \multicolumn{2}{|c}{ Item } & \multicolumn{2}{c|}{ Current Operation } & \multicolumn{2}{c|}{ Modified Operation } & Result \\
\cline { 3 - 6 } & Safety(\%) & Shortage(Day) & Safety(\%) & Shortage(Day) & \\
\hline \multicolumn{2}{|c|}{ Cikalong Intake Station } & 97.3 & 108 & 98.2 & 73 & $\mathbf{\Delta} 0.9$ \\
\hline Pataruman & Q95\% & 63.1 & 1,481 & 64.3 & 1,436 & $\boldsymbol{\Delta} 1.2$ \\
\hline Irritation & Ciherang & 94.5 & 223 & 95.3 & 190 & $\mathbf{\Delta} 0.8$ \\
\hline
\end{tabular}

WATER BALANCE ANALYSIS

CONSIDERING IMPLEMENTATION OF STRUCTURAL MEASURES

In order to analyse the scenario on the structural measures, the effect of new dam construction and reservoir dredging was reviewed considering the increased inflow scenario.
Review of water supply plan with new Santosa dam construction

In the Cikalong water intake in the project area, $1.4 \mathrm{~m}^{3} / \mathrm{s}$ of additional water was planned to supply to Bandung by construction of new Santosa dam (BBWSC, 2011). In order to evaluate the effect of new Santosa dam construction, result of 
WBA reflecting new dam development condition was compared to WBA result based on current water supply system. Review condition and result are shown as follow.

\section{Analysis Condition}

1. Period: 2002 2012 (11years, Daily)

2. Intake(Cikalong) : $1.9 \mathrm{~m}^{3} / \mathrm{s}$ (Current), 3.3 $\mathrm{m}^{3} / \mathrm{s}$ (New dam plan)

3. hydropower plants: Monthly average generation capacity, 9 years (2004 2012)

\section{Result}

Table 6 summarizes the results of WBA based on current water supply system with the scenarios of present and planned intake capacity. In case of applying the planned intake $\left(3.3 \mathrm{~m}^{3} / \mathrm{s}\right)$ under current water supply system, water supply safety was decreased by $8.3 \%(92.3 \rightarrow 84.0)$ at the Cikalong Intake and decreased by $12.5 \%$ $(75.3 \rightarrow 62.8)$ at the Pataruman gauge station in the Cisangkuy river (Q95\% condition) respectively in comparison with present intake condition (1.9 $\mathrm{m}^{3} / \mathrm{s}$ ). The analysis results indicate that additional water capacity is necessary to meet the increased water demand.

Additionally, In order to review the effect of additional water supply from the Santosa dam construction, water balance analysis for 96 scenarios with different water supply from the new dam in combination with different set of micro hydropower plant operation rules. As shown in Table 7, water supply safety was increased with the scenario of additional dam water supply more than $1.5 \mathrm{~m}^{3} / \mathrm{s}$ and $60 \%$ power plant operation during wet season, and $40 \%$ operation during dry season in comparison with current water supply system.

\section{Evaluation on the effect of new Cikalong dam construction}

The Cikalong dam is tentatively under planned with 80,000 ton of storage, with 0.35 $\mathrm{m}^{\mathrm{a}} / \mathrm{s}$ of additional water supply to Cikalong intake station. Water balance analysis was conducted considering new Cikalong dam just downstream at the existing Cikalong intake station. And the effects of the new regulating dam construction to the downstream were evaluated as below;

1. Intake capacity (Dry season) - Evaluate through observation flow

2. Capacity for supplying $0.35 \mathrm{~m}^{3} / \mathrm{s}$ in dry season - Safety degree of water shortage

3. Effects evaluation in downstream - Safety degree of water shortage (Pataruman, Ciherang)

Analysis condition and result were shown as follows.

Table 6 Results of Water Budget Analysis based on Current Water Supply System

\begin{tabular}{|c|c|c|c|c|c|c|c|}
\hline \multirow{2}{*}{\multicolumn{2}{|c|}{ Classification }} & \multirow[b]{2}{*}{ Qpower } & \multicolumn{3}{|c|}{ Current Condition $\left(1.9 \mathrm{~m}^{3} / \mathrm{s}\right)$} & \multicolumn{2}{|c|}{$\begin{array}{c}\text { Planned Intake } \\
\text { Condition }\left(3.3 \mathrm{~m}^{3} / \mathrm{s}\right)\end{array}$} \\
\hline & & & $\begin{array}{l}\text { Simulation } \\
\text { (Days) }\end{array}$ & $\begin{array}{l}\text { Shortage } \\
\text { (Days) }\end{array}$ & $\begin{array}{l}\text { Water Supply } \\
\text { Safety } \\
\text { (\%) }\end{array}$ & $\begin{array}{l}\text { Simulation } \\
\text { (Days) }\end{array}$ & $\begin{array}{l}\text { Water Supply } \\
\text { Safety } \\
\text { (\%) }\end{array}$ \\
\hline \multicolumn{2}{|c|}{ Cikalong Intake } & \multirow{3}{*}{$\begin{array}{l}5 \text { year } \\
\text { Average }\end{array}$} & \multirow{3}{*}{4,018} & 309 & 92.3 & 642 & 84.0 \\
\hline \multirow{2}{*}{$\begin{array}{l}\text { Pataruman } \\
\text { Gage }\end{array}$} & Q355 & & & 953 & 76.3 & 1,409 & 64.9 \\
\hline & Q95\% & & & 993 & 75.3 & 1,493 & 62.8 \\
\hline
\end{tabular}

Table 7 Results of Water Budget Analysis reflecting New Dam Development Condition

\begin{tabular}{|c|c|c|c|c|c|c|c|}
\hline \multirow{3}{*}{ Scenario } & \multicolumn{4}{|c|}{ Simulation Condition } & \multicolumn{3}{|c|}{ Water Supply Safety (\%) } \\
\hline & \multirow{2}{*}{$\begin{array}{c}\text { Santosa Dam } \\
\left.\text { W S (m } \mathrm{m}^{3} / \mathrm{s}\right)\end{array}$} & \multicolumn{2}{|c|}{ Power Plant Operation(\%) } & \multirow{2}{*}{$\begin{array}{l}\text { Qintake } \\
\left(\mathrm{m}^{3} / \mathrm{s}\right)\end{array}$} & \multirow{2}{*}{$\begin{array}{l}\text { Cikalong } \\
\text { Intake }\end{array}$} & \multicolumn{2}{|c|}{ Pataruman } \\
\hline & & Wet Season & Dry Season & & & Q95\% & Q355 \\
\hline- & - & 60 & 40 & 1.9 & 92.14 & 73.69 & 74.42 \\
\hline 50 & 1.5 & 50 & 40 & 3.3 & 95.99 & 82.85 & 86.36 \\
\hline 54 & 1.5 & 60 & 40 & 3.3 & 94.90 & 79.99 & 83.20 \\
\hline 73 & 2 & 50 & 50 & 3.3 & 96.34 & 83.08 & 83.55 \\
\hline 74 & 2 & 50 & 40 & 3.3 & 97.83 & 88.05 & 91.74 \\
\hline 78 & 2 & 60 & 40 & 3.3 & 97.83 & 84.79 & 88.63 \\
\hline 82 & 2 & 70 & 40 & 3.3 & 97.04 & 82.75 & 86.11 \\
\hline
\end{tabular}




\section{Analysis condition}

Analysis condition to evaluate the effect of the new dam construction is shown as below;

1. Period: 2002 2012 (11years, Daily)

2. Intake $1.9 \mathrm{~m}^{3} / \mathrm{s}$ at Cikalong intake station

3. Intake $0.35 \mathrm{~m}^{3} / \mathrm{s}$ from new Cikalong regulating dam $\left(\mathrm{V}=80,000 \mathrm{~m}^{3} / \mathrm{s}\right)$

4. hydropower plants: Monthly average generation capacity, 9 years (2004 2012)

\section{Result}

According to the result at reviewing flow data in 2002 2012 dry season at Pataruman, average flow was $3.6 \mathrm{~m}^{3} / \mathrm{s}$ which was enough to keep storage for the new dam with the volume at $80,000 \mathrm{~m}^{3}$.

As shown in the Table 8, consistent water supply $\left(0.35 \mathrm{~m}^{3} / \mathrm{s}\right)$ is possible at Cikalong intake station. However, water supply safety regarding water shortage at Pataruman for river maintenance flow and Ciherang irrigation water were decreased $2.4 \sim 4.2 \%$.

\section{Review of the changing reservoir volume with dredging impact}

For the analysis of dredging impact, reservoir storage capacity curve for Cipanunjang and Cileunca reservoirs were extracted using the TIN data from survey map in 2009. Since there was no CAD or GIS data available, the image in the report was scanned and then applied to digital map.

Analysis condition applied new storage capacity curve and result were shown as follows.

\section{Analysis Condition}

Period: 2002 2012 (11years, Daily)

1. Reservoir operation : Applied representative existing operation curve

2. Intake $1.9 \mathrm{~m}^{3} / \mathrm{s}$ water from Cikalong intake station

3. Operating 3 hydropower plants: Monthly average generation capacity, 9 years (2004 2012)

4. Water budget analysis with GIS based storage capacity curve.

\section{Result}

The result of water balance analysis considering reservoir sedimentation was identical with that in current water supply system condition. It means that, since the most sediment was located under D.W.L, sediment had no effect to analysis. The volume at sedimentation estimated in this analysis using GIS data was 2.1 $\mathrm{Mm}^{3}$ less than that in the 2009 report. And it was revealed that there was difference in the volume between the high water level and low water level at the reservoirs. It is assumed that these errors come from the difference in scale between the plan map at the report and CAD numerical topographical map and interpolation. Therefore, considering low accuracy and precision of this GIS based storage capacity curve, more detail sediment investigation and precise measurement are required.

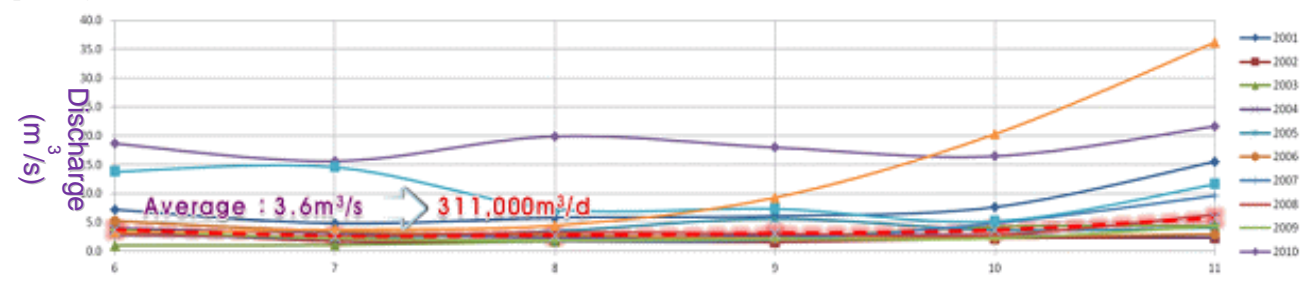

Figure 6 Monthly Average flow at Pataruman Station (Jun Nov)

Table 8 Effects of new Cikalong dam construction

\begin{tabular}{c|c|c|c|c|c|c}
\hline \multirow{2}{*}{\multicolumn{2}{c|}{ Item }} & \multicolumn{2}{c|}{ Before } & \multicolumn{2}{c}{ After } & \multirow{2}{*}{ Result } \\
\cline { 3 - 7 } & Safety(\%) & Shortage(Day) & Safety(\%) & Shortage(Day) & \\
\hline \multicolumn{2}{c}{ Cikalong Intake Station } & 97.3 & 108 & 97.9 & 81 & $\boldsymbol{\Delta} 0.6$ \\
\hline Pataruman & Q95\% & 63.1 & 1,481 & 58.9 & 1,612 & $\boldsymbol{\nabla} 4.2$ \\
\hline Irrigation & Ciherang & 94.5 & 223 & 92.1 & 319 & $\boldsymbol{\nabla} 2.4$ \\
\hline
\end{tabular}

Table 9 Water Balance Analysis considering Sediment

\begin{tabular}{c|c|c|c|c|c|c}
\hline \multirow{2}{*}{ Item } & \multicolumn{2}{c|}{ Current Operation } & \multicolumn{2}{c}{ Operation with sediment } & \multirow{2}{*}{ Result } \\
\cline { 2 - 7 } & Safety(\%) & Shortage(Day) & Safety(\%) & Shortage(Day) & 108 \\
\hline \multicolumn{2}{c}{ Cikalong Intake } & 97.3 & 108 & 97.3 & - & 1,481 \\
\hline Pataruman & Q95\% & 63.1 & 1,481 & 63.1 & - & 223 \\
\hline Irrigation & Ciherang & 94.5 & 223 & 94.5 & - \\
\hline
\end{tabular}




\section{CONCLUSION}

This paper introduced preliminary analysis results of initial phase study to examine potential effectiveness and feasibility of applying smart water management technologies. So this paper dealed with the spatial-temporal water balance analysis and presented the results of effect analysis with regard to implementation of structural measures and non-structural measures such as dam construction and implementation of optimal water facilities operation.

As a result of preliminary analysis regarding 4 different scenarios, it was founded that implementation of non-structural measures besides structural measures will contribute not only securing additional water but also improvement of water facilities management efficiency. The result of water balance analysis considering new reservoir operation curve as a non-structural measures shows that the power generation capacity and water supply safety are improved (1.4 2.6\% and 0.8 1.2\% respectively) and water shartage is decreased by 33 days $(223 \rightarrow 190)$. Also according to the results of analysis based on current water supply system with the scenarios of present $\left(1.9 \mathrm{~m}^{3} / \mathrm{s}\right)$ and planned intake capacity $\left(3.3 \mathrm{~m}^{3} / \mathrm{s}\right)$, indicate that additional water supply is necessary to meet the increased water demand. In case of additional water supply from the Santosa dam, water supply safety was increased with the scenario of additional dam water supply more than $1.5 \mathrm{~m}^{3} / \mathrm{s}$ and $60 \%$ power plant operation during wet season. In case of new Cikalong dam construction which is under planed with 80,000 ton of storage, additional consistent water supply $\left(0.35 \mathrm{~m}^{3} / \mathrm{s}\right)$ is possible at Cikalong intake station. However, water supply safety regarding water shortage at Pataruman for river maintenance flow and Ciherang irrigation water were decreased by 2.4 4.2\%.

Subsequent stage research outcome will examine how ICT can bring enormous benefits to water authorities in mapping and monitoring natural water resources, water facilities operation as well as in forecasting river flows and advanced prediction in water related emergency situations such as severe drought. Furthermore, sophisticated ICT including sensor networks and Internet communications combined with GIS tools will be having an important role in the future and can be very beneficial to water management authorities in not only efficiently managing the water supply but also in water quality management.

\section{ACKNOWLEDGEMENTS}

This research was financially supported by KAIA (Korea Agency for Infrastructure Technology Advancement) through the international collaborative R\&D program (15CTAP-C096288).

\section{REFERENCES}

BBWSC, 2011. Final Design Report for Santosa Dam, BBWSC, Bandung.

CSU, 2010. MODSIM 8.1 User Manual and Documentation: CSU, U.S.A.

D. Subarna, M.J. Purwanto, K. Murtilaksono, Wiweka, 2014. The relationship between monthly rainfall and elevation in the Cisangkuy watershed Bandung Regency: International Journal of Latest Research in Science and Technology, Vol. 3, pp. 55-60.

IBM, 2013. IBM Intelligent Water. http://www935.ibm.com/services/multimedia/Intellig ent_Water.pdf [accessed on 18 January 2017]

ITU Tele-communication Standardization Bureau, 2010. ICT as an enabler for smart water management: ITU-T technology watch report, ITU.

J.H. Kim, 2011. Korean research direction for smart water grid: Proceedings of the 2011 1st International Workshop on Smart Water Grid, pp. 75-100.

P. Williams ,2010. Water Technology Trends: A Forward Look, Dayton Water Conference, May 10, Dayton, U.S.A.

S.W. Lee, S. Sarp, D.J. Jeon, J.H. Kim, 2015. Smart water grid: the future water management platform: Desalination and Water Treatment, Vol. 55, pp. 339-346.

Smart Water Grid Research Group, 2012. Background of SWG (in terms of water industry). http://www.swg.re.kr/english/sub/project /background.htm [accessed on 18 January 2017]

Yooshin Engineering Corporation, 2013. Feasibility Study and Basic Engineering Design for Water Conveyance and Integrated Dam Operating System for the Bandung Area: Final Report, KOICA, Korea. 